\title{
HOUSEHOLD FOOD INSECURITY IS ASSOCIATED WITH BINGE EATING DISORDER AMONG ADOLESCENT IN SEMAMPIR DISTRICT, SURABAYA, INDONESIA
}

\author{
Dian Puteri Andani ${ }^{*}$, Annis Catur Adi ${ }^{2}$ \\ ${ }^{1}$ Bachelor Program of Nutrition, Faculty of Public Health, Universitas Airlangga, Indonesia \\ ${ }^{2}$ Department of Nutrition, Faculty of Public Health, Universitas Airlangga, Indonesia \\ *E-mail: dianputeria@gmail.com
}

\begin{abstract}
Teenage phase is a critical period of psychosocial development. Adolescent eating patterns are formed in this phase. Household food security is among factors which may influence eating pattern. Adolescent who are exposed to food insecure condition tend to experience stress, which one of the coping mechanisms is overeating and may develop binge eating disorder. The purpose of this study is to analyze association between household food security status and binge eating disorder in adolescent. This case control study involved 74 adolescents aged 16-18 years and their parents in Semampir District, Surabaya, Indonesia who were selected randomly using simple random sampling. Household food security was assessed by using the Household Food Insecurity Access Scale (HFIAS) and binge eating disorder is assessed by using Eating Disorder Diagnostic Scale (EDDS). The association between household food security and binge eating disorder was analyzed by Spearman's correlation test. There was an association between food security status $(\mathrm{p}=0,001)$ and binge eating disorder. Further analysis showed that adolescents at risk of food insecurity were 5,625 times more likely to experience a binge eating disorder. This study recommends to increase food security through economic empowerment of housewives and socialization about coping strategy for both parent and adolescent.
\end{abstract}

Keywords: binge eating, eating disorder, food security, adolescent

\section{INTRODUCTION}

Binge Eating Disorder (BED) is an eating disorder characterized by consuming large amounts of food in a relatively short time accompanied by an inability to control the amount of food consumed and followed by feelings of guilt, shame and disgust (APA, 2013). Dietary disorders are a serious threat and represent a huge burden of health problems due to their potential long-term health problems. The effects of eating disorders vary, ranging from low body mass index, mental health disorders, changes in menstrual function, infertility, and complications during pregnancy such as low birth weight and gestational diabetes (O 'Brian et al., 2017).

Symptoms of eating disorders that consistently limit food can trigger to binge eating and overeating as much as $17 \%$ from long-term food insecurity (Becker et al., 2017). While food insecure occurs, adolescents feel worse because they have lower self-esteem (Popkin et al., 2016). Micali, et al. (2014) study showed that among food insecure adolescents, $29 \%$ had health problems, $26 \%$ had social interaction problems, $22 \%$ were hyperactive and $20 \%$ had problems with social groups. This is thought to occur due to a period of brain development which resulted in suboptimal nutrition and increased psychological stress. The peak of eating disorders is at the age of 15 to 19 years.

The Economist Intelligence Unit states in the 2018 Global Food Security Index that Indonesia is ranked $65^{\text {th }}$ out of 113 countries, with a score of 54.8 from a maximum value of 100 (EIU, 2018). Food insecurity can lead to obesity because energydense foods are cheaper than nutrient-dense foods (Tester et al., 2016).

Food insecurity is closely related to poverty. One of the areas with the highest number of poor people in the Surabaya based on the aspects of work, food and housing is Semampir District as evidenced by $55 \%$ pre-prosperous family cards II [Kartu Keluarga Pra-Sejahtera II] (Belinda and Rahmawati, 2017; Normanda and Rahmawati, 2013). This statement is supported by Setijaningrum (2017) which states that $60.41 \%$ of the population in Semampir District are poor and Jayarni (2018) with $54.9 \%$ of households in 
Semampir District are in a food insecure condition accompanied by moderate hunger. This study aims to analyze the relationship between household food security and binge eating disorder among adolescents in Semampir District, Surabaya, Indonesia.

\section{METHODS}

This was an observational study used a case control design with a case group was adolescents with Binge Eating Disorder (BED) and a control group was adolescents without BED. The adolescent population is all active students in $10^{\text {th }}$ and $11^{\text {th }}$ grade, SMAN 8 Surabaya and Al Irsyad Private High School Surabaya. The inclusion criteria in this study were adolescents who lived in Semampir District at the time of data collection. Meanwhile, the exclusion criteria included students who were dieting, sick or suffering from certain diseases, and height or weight could not be measured.

Samples were taken using simple random sampling technique by first screening using the Eating Disorder Diagnostic Scale (EDDS) instrument. The sample sizes were 37 in each of case and control groups. Adolescents were randomly selected if they met the inclusion requirements and were willing to be interviewed. Then BED adolescents and parents became the sample case group and non-BED adolescents and parents became the control group sample. In this study, matching was not performed due to the limited number of case populations.

Household food security status was assessed using the Household Food Insecurity Access Scale (HFIAS) instrument. In addition, the variables studied were the characteristics of adolescents and adolescent families including age, gender, amount of pocket money, parent's occupation, family economic status and number of family members.

The inferential statistics used was Spearman correlation test to see the relationship between

Table 1. Age Descriptive Data

\begin{tabular}{lccc}
\hline & Min & Max & Median \\
\hline Case & 15 & 17 & 16 \\
Control & 15 & 18 & 16 \\
\hline
\end{tabular}

household food security and BED in adolescents and said to be related if $p<0.05$.

\section{RESULTS AND DISCUSSION}

\section{Respondent Characteristics}

Table 1 shows that the majority of adolescents in both groups $(59.5 \%$ in BED adolescents and $56.8 \%$ in non-BED adolescents) were 16 years old. According to Brown (2013), this age is included in the middle adolescent phase from the ages of 15-17 years. Research by Allen et al. (2013) showed that $44 \%$ of adolescents experience eating disorders at the ages of 17 and 20.

The gender of respondents was mostly girls (86.5\% in BED adolescents and 59.5\% in nonBED adolescents). BED is more often seen as an eating disorder associated with girls, while boys are reluctant to admit that the BED phase is a problem (Lee-Winn et al., 2016). The distribution of the amount of allowance was mostly $<$ IDR $10,000(32.4 \%$ for BED adolescents and $67.6 \%$ for non-BED adolescents).

Most family heads work as laborers $(27 \%$ for BED adolescents and $35.1 \%$ for non-BED adolescents). Heads of poor households in urban areas are closely related to low education and tend to work as laborers or employees or employees or others (BPS, 2015).

Teenage mothers were mostly unemployed (54.1\% in BED adolescents and $48.6 \%$ in nonBED adolescents). Based on research conducted by Zulaiha (2018), working housewives have an influence on household food security. With the presence of family members who work, in this case a mother is expected to be able to help her husband meet the needs of the family, whether it is food, shelter, education or family support facilities. Therefore, by looking for additional income, housewives can help their husbands.

Household income for BED adolescents is mostly $\leq$ Rp 3,000,000 with a total of 15 household $(40.5 \%)$. While the household income of nonBED adolescents is mostly $>$ Rp. 6,000,000 with a total of 12 household (32.4\%). Food insecurity and family income are so closely related that poor families are 3 times more vulnerable to experiencing food insecurity than others (Nord 
Table 2. Distribution of Respondent Characteristics

\begin{tabular}{|c|c|c|c|c|c|c|c|}
\hline \multirow[t]{2}{*}{ Variable } & \multicolumn{2}{|c|}{$\begin{array}{c}\text { Case } \\
(n=37)\end{array}$} & \multicolumn{2}{|c|}{$\begin{array}{c}\text { Control } \\
(n=37)\end{array}$} & \multicolumn{2}{|c|}{$\begin{array}{c}\text { Total } \\
(\mathrm{N}=74)\end{array}$} & \multirow[t]{2}{*}{ p-value } \\
\hline & n & $\%$ & $\mathbf{n}$ & $\%$ & $\mathbf{N}$ & $\%$ & \\
\hline \multicolumn{8}{|l|}{ Age } \\
\hline 15 & 8 & 21.6 & 9 & 24.3 & 17 & 23.0 & \multirow{4}{*}{0.820} \\
\hline 16 & 22 & 59.5 & 21 & 56.8 & 43 & 58.1 & \\
\hline 17 & 7 & 18.9 & 6 & 16.2 & 13 & 17.6 & \\
\hline 18 & 0 & 0 & 1 & 2.7 & 1 & 1.4 & \\
\hline \multicolumn{8}{|l|}{ Sex } \\
\hline Boys & 5 & 13.5 & 15 & 40.5 & 20 & 27.0 & \multirow{2}{*}{0.008} \\
\hline Girls & 32 & 86.5 & 22 & 59.5 & 54 & 73.0 & \\
\hline \multicolumn{8}{|l|}{ Pocket money } \\
\hline$<\operatorname{Rp} 10.000$ & 12 & 32.4 & 25 & 67.6 & 37 & 50.0 & \multirow{4}{*}{0.052} \\
\hline Rp 10.000 - Rp 15.000 & 8 & 21.6 & 3 & 8.1 & 11 & 14.9 & \\
\hline Rp $15.000-R p 20.000$ & 11 & 29.7 & 5 & 13.5 & 16 & 21.6 & \\
\hline$>\operatorname{Rp} 20.000$ & 6 & 16.2 & 4 & 10.8 & 10 & 13.5 & \\
\hline \multicolumn{8}{|l|}{ Father's occupation } \\
\hline Not working & 7 & 18.9 & 1 & 2.7 & 8 & 10.8 & \multirow{6}{*}{0.359} \\
\hline Freelance & 8 & 21.6 & 5 & 13.5 & 13 & 17.6 & \\
\hline Trader & 5 & 13.5 & 10 & 27.0 & 15 & 20.3 & \\
\hline Labor & 10 & 27.0 & 13 & 35.1 & 23 & 31.1 & \\
\hline Govt employee & 3 & 8.1 & 1 & 2.7 & 4 & 5.4 & \\
\hline Army/Policeman & 4 & 10.8 & 7 & 18.9 & 11 & 14.9 & \\
\hline \multicolumn{8}{|l|}{ Mother's occupation } \\
\hline Not working & 20 & 54.1 & 18 & 48.6 & 38 & 51.4 & \multirow{6}{*}{0.432} \\
\hline Freelance & 4 & 10.8 & 4 & 10.8 & 8 & 10.8 & \\
\hline Trader & 2 & 5.4 & 7 & 18.9 & 9 & 12.2 & \\
\hline Labor & 6 & 16.2 & 1 & 2.7 & 7 & 9.5 & \\
\hline Govt employee & 5 & 13.5 & 7 & 18.9 & 12 & 16.2 & \\
\hline Army/Policeman & 0 & 0.0 & 0 & 0.0 & 0 & 0.0 & \\
\hline \multicolumn{8}{|l|}{ Household income } \\
\hline$\leq \operatorname{Rp} 3.000 .000$ & 15 & 40.5 & 11 & 29.7 & 26 & 35.1 & \multirow{4}{*}{0.009} \\
\hline$>$ Rp3.000.000- $\leq$ Rp 5.000 .000 & 12 & 32.4 & 5 & 13.5 & 17 & 23.0 & \\
\hline$>$ Rp5.000.000- $\leq$ Rp6.000.000 & 5 & 13.5 & 9 & 24.3 & 14 & 18.9 & \\
\hline$>\operatorname{Rp} 6.000 .0000$ & 5 & 13.5 & 12 & 32.4 & 17 & 23.0 & \\
\hline \multicolumn{8}{|l|}{ Family number } \\
\hline$\leq 4$ & 12 & 32.4 & 11 & 29.7 & 23 & 31.1 & \multirow{2}{*}{0.805} \\
\hline$>4$ & 25 & 67.6 & 26 & 70.3 & 51 & $69, .6$ & \\
\hline
\end{tabular}

Table 3. Results of Multivariate Analysis of Respondent Characteristics

\begin{tabular}{lcccc}
\hline \multicolumn{1}{c}{ Variable } & Phase 1 & Phase 2 & Phase 3 & Phase 4 \\
\hline Gender & $5.77(1.55-21.44)^{*}$ & $5.33(1.42-19.8)^{*}$ & $5.52(1.48-20.51)^{*}$ & \\
Pocket money & $4.43(1.33-14.7)^{*}$ & & $4.26(1.27-14.14)^{*}$ & $4.02(1.20-13.36)^{*}$ \\
Household income & $0.18(0.05-0.58)^{*}$ & $0.19(0.05-0.61)^{*}$ & & $0.20(0.05-0.63)^{*}$ \\
\hline
\end{tabular}

$* \mathrm{p}<0.05$ 
and Hopwood, 2008). Sharp price increases for some basic commodities can cause food insecurity, especially in households with incomes near the poverty line, so government policies must help create jobs and stabilize prices (Yadegari et al., 2017).

The family member is mostly more than 4 (67.6\% in BED adolescents and $70.3 \%$ in non-BED adolescents). Sharafkhani et al. (2010) revealed that food insecure household conditions were not related to the number of children. However, the presence of toddlers and elderly among family members can increase the risk of food insecurity. Financial support and nutrition education programs can reduce the risk of household food insecurity.

The variables included in the multivariate analysis were gender, amount of pocket money and household income. Parents' occupation, age and number of family members were not included in the analysis because they did not qualify the requirement to enter multivariate analysis. Table 3 shows that these three factors are not a confounding factor, because they meet the requirements with a p-value $<0.05$ and do not cause a change $>10 \%$ of the $\mathrm{OR}$ value.

\section{The Relationship between Household Food Security and Binge Eating Disorder}

Based on Table 4, the food security variables are categorized into two, i.e., food resistance and food insecurity. Food insecure households were 5.625 times more likely to experience BED than food resistant households $(p=0.001)$. In line with the findings of Bruening et al. (2012) and Becker et al., (2017), the prevalence of BED is higher in insecure conditions than individuals who are in food secure conditions. Due to uncertain food availability, physiological and psychological hunger can increase the likelihood of binge eating (West et al., 2019). Olson et al. (2007) also found a cycle of limitations and overeating in food insecure households, where when a family is able to get food, binge eating will occur. Meanwhile, when there is not enough food, parents will tend to limit the food consumed (Castner and Henke, 2011).

Eating disorders can occur in all individuals of all ages. In adolescents, the increased prevalence of BED can occur in early adolescence and late adolescence. Smink et al. (2014) study explained that BED occurs immediately after puberty, with a mean age of 14 years. While study of Stice et al. (2013) among female subjects revealed that BED occurred in late adolescence between 18 to 20 years of age. This is supported by the research of Brewerton et al. (2014) which also among female subjects who were divided into two categories; adolescents $<18$ years and adults $\geq 18$ years, showing that BED in adults $(70 \%$ experienced BED for the first time in adults, with mean age 27.7 years with an age range of $16.7-38.7$ years) twice as common as adolescents ( $30 \%$ experienced BED for the first time during the transition from children to adolescents with a mean age of 13.9 years from the age range $11.1-16.7$ years).

Mitchison et al. (2014) found that the prevalence of BED in respondents who were below the median value of household income was higher than those who were above the median household income. The existence of a food restriction pattern and binge eating are a cycle that is often experienced by many individuals with low income (Rasmusson et al., 2019). Adolescents from low socioeconomic origin with food insecurity and not having enough food tend to have similarities to dietary restriction behavior and are believed to encourage binge eating behavior. Also, low socioeconomic conditions allow adolescents to be more exposed to stressful environments (West et al., 2019).

Table 4. The Relationship between Household Food Security and Binge Eating Disorder

\begin{tabular}{|c|c|c|c|c|c|c|c|c|c|c|}
\hline \multirow[t]{2}{*}{ Variable } & \multicolumn{2}{|c|}{$\begin{array}{c}\text { Case } \\
(n=37)\end{array}$} & \multicolumn{2}{|c|}{$\begin{array}{c}\text { Control } \\
(n=37)\end{array}$} & \multicolumn{2}{|c|}{$\begin{array}{c}\text { Total } \\
(\mathrm{N}=37)\end{array}$} & \multirow[t]{2}{*}{ p-value } & \multirow[t]{2}{*}{ OR } & \multicolumn{2}{|c|}{$95 \% \mathrm{CI}$} \\
\hline & $\mathbf{n}$ & $\%$ & $\mathbf{n}$ & $\%$ & $\mathbf{n}$ & $\%$ & & & Lower & Upper \\
\hline Food secure & 10 & 27.0 & 25 & 67.6 & 35 & 47.3 & \multirow{4}{*}{0.001} & \multirow{4}{*}{5.625} & \multirow{4}{*}{2.069} & \multirow{4}{*}{15.292} \\
\hline Mildly food insecure & 7 & 19.0 & 3 & 8.1 & 10 & 13.5 & & & & \\
\hline Moderately food insecure & 10 & 27.0 & 6 & 16.2 & 16 & 21.6 & & & & \\
\hline Severely food insecure & 10 & 27.0 & 3 & 8.1 & 13 & 17.6 & & & & \\
\hline
\end{tabular}


Food insecure households tended to be more associated with the incidence of BED. This research supports the theory that food insecurity can also have an impact on the risk of developing BED, which is conceptualized in a cycle of limitations and overeating, both when externally limited such as financial difficulties and internally such as limiting food to reduce body weight (Fairburn, 2013).

Adolescents in food insecure household have a higher rate of mental health problems (Salvo et al., 2016). The experience of not having adequate access to food often leads to feelings of anxiety, stress and depression, which in turn can lead to behaviors that increase the risk of obesity. These behaviors include binging or overeating when food is available or choosing energy-dense foods rich in sugar, salt and fat. These foods have physiological effects that can suppress stress in the short term (FAO, 2018).

Stress is a challenge to the natural homeostasis of an organism, so that at some point, the organism can react to stress by providing a physiological response to regain the balance lost due to the impact of these stressors. One of the disturbed homeostatic conditions is eating behavior (Yau and Potenza, 2013). Chronic stress is associated with BED because it affects biochemical pathways that negatively impact appetite and eating behavior (Sojcher et al., 2012). Stress can occur emotionally and physiologically. Emotionally includes interpersonal conflicts, loss of loved ones, dismissal, and so on. Meanwhile, physiologically includes lack of food, disease, and rehabilitation from narcotics (Fragkos and Farngos, 2013).

\section{CONCLUSION}

Household food insecurity is associated with binge eating disorder. Binge Eating Disorder adolescents are often found in food insecure households. Binge eating is a coping mechanism in dealing with stress in food insecure household conditions.

Increasing household food security needs to be done through increasing productivity by empowering the economy of housewives. Further research on a history of eating disorders is also necessary because binge eating can also be triggered by Anorexia Nervosa. In addition, it is necessary to increase adolescent knowledge about stress coping strategies in overcoming food insecurity conditions.

\section{REFERENCES}

Allen, K.L., Byrne, S.M., Oddy, W.H. \& Crosby, R.D. (2013). Early onset binge eating and purging eating disorders: Course and outcome in a population-based study of adolescents. Journal of Abnormal Child Psychology, 41(7), 10831096. doi:10.1007/s10802-013-9747-7.

American Psychiatric Association (APA). (2013). Diagnostic and statistical manual of mental disorders (DSM-5). Arlington: American Psychiatric Pub.

Badan Pusat Statistik (BPS). (2015). Indikator Kesejahteraan Rakyat 2015. Jakarta: BPS Jakarta.

Becker, C.B., Middlemass, K., Taylor, B., Johnson, C. \& Gomez, F. (2017). Food insecurity and eating disorder pathology. International Journal of Eating Disorders, 50(9), 1031-1040. doi:10.1002/eat.22735.

Belinda, N. \& Rahmawati, D. (2017). Pengembangan urban farming berdasarkan preferensi masyarakat Kecamatan Semampir Kota Surabaya. Jurnal Teknik ITS, 6(2), 165-168. Retrieved from http://repository.its.ac.id/id/eprint/43952

Brewerton, T.D., Rance, S.J., Dansky, B.S., O'neil, P.M. \& Kilpatrick, D.G. (2014). A comparison of women with child-adolescent versus adult onset binge eating: Results from the National Women's Study. International Journal of Eating Disorders, 47(7), 836-843. doi:10.1002/ eat.22309.

Brown, J.E. (2013). Nutrition through the life cycle. New York: Cengage learning

Bruening, M., MacLehose, R., Loth, K., Story, M. \& Neumark-Sztainer, D. (2012). Feeding a family in a recession: food insecurity among Minnesota parents. American journal of public health, 102(3), 520-526. doi:10.2105/ AJPH.2011.300390

Castner, L. \& Henke, J. (2011). Benefit redemption patterns in the supplemental nutrition assistance program. Washington, D.C: Mathematica Policy Research.

Fairburn, C.G. (2013). Overcoming binge eating: The proven program to learn why you binge and how you can stop. New York: Guilford Press. 
FAO, IFAD, UNICEF, WFP \& WHO. (2018). The state of food security and nutrition in the world 2018. Building climate resilience for food security and nutrition. Rome, FAO.

Fragkos, K. \& Frangos, C. (2013). Assessing eating disorder risk: the pivotal role of achievement anxiety, depression and female gender in nonclinical samples. Nutrients, 5(3), 811-828. doi: 10.3390/nu5030811

Jayarni, D.E. \& Sumarmi, S. (2018). Hubungan ketahanan pangan dan karakteristik keluarga dengan status gizi balita usia 2-5 tahun (studi di wilayah kerja Puskesmas Wonokusumo Kota Surabaya). Amerta Nutrition, 2(1), 44-51. doi: 10.20473/amnt.v2i1.2018.44-51

Lee-Winn, A.E., Reinblatt, S.P., Mojtabai, R. \& Mendelson, T. (2016). Gender and racial/ethnic differences in binge eating symptoms in a nationally representative sample of adolescents in the United States. Eating behaviors, 22, $27-$ 33. doi:10.1016/j.eatbeh.2016.03.021.

Micali, N., Ploubidis, G., De Stavola, B., Simonoff, E. \& Treasure, J. (2014). Frequency and patterns of eating disorder symptoms in early adolescence. Journal of Adolescent Health, 54(5), 574-581. doi: 0.1016/j. jadohealth.2013.10.200.

Mitchison, D., Hay, P., Slewa-Younan, S. \& Mond, J. (2014). The changing demographic profile of eating disorder behaviors in the community. BMC Public Health, 14(1), 943. doi:10.1186/1471-2458-14-943.

Normanda, R. \& Rahmawati, D. (2013). Identifikasi faktor penyebab kemiskinan kota di kecamatan Semampir, Surabaya. Jurnal Teknik POMITS, 2(1). Retrieved from https:// docplayer.info/31815795-Identifikasi-faktorpenyebab-kemiskinan-kota-di-kecamatansemampir-surabaya.html

Nord, M. \& Hopwood, H. (2008). A comparison of household food security in Canada and the United States. U.S. Department of Agriculture

O'Brien, K.M., Whelan, D.R., Sandler, D.P., Hall, J.E. \& Weinberg, C.R. (2017). Predictors and long-term health outcomes of eating disorders. PloS one, 12(7), e0181104. doi: 10.1371/journal.pone.0181104.

Olson, C.M., Bove, C.F. and Miller, E.O. (2007). Growing up poor: long-term implications for eating patterns and body weight. Appetite, 49(1), 198-207. doi: 10.1016/j.appet.2007.01.012

Poole-Di Salvo, E., Silver, E. J., \& Stein, R. E. (2016). Household food insecurity and mental health problems among adolescents: what do parents report?. Academic pediatrics, 16(1), 90-96. doi:10.1016/j.acap.2015.08.005

Popkin, S.J., Scott, M.M. \& Galvez, M. (2016). Impossible choices: teens and food insecurity in America. Urban Institute and Feeding America.

Rasmusson, G., Lydecker, J.A., Coffino, J.A., White, M.A. \& Grilo, C.M. (2019). Household food insecurity is associated with binge-eating disorder and obesity. International Journal of Eating Disorders, 52(1), 28-35. doi:10.1002/ eat.22990.

Sharafkhani, R., Dastgiri, S., Gharaaghaji, R., Ghavamzadeh, S. \& Didarloo, A. (2010). The role of household structure on the prevalence of food insecurity. Eur J Gen Med, 7(4), 385-388. doi: $10.29333 /$ ejgm $/ 82890$

Setijatiningrum, E., (2017). Program terpadu penanggulangan kemiskinan di Kota Surabaya. Masyarakat, Kebudayaan dan Politik, 30(1), 13-19. doi: 10.20473/mkp. V30I12017.13-19

Smink, F.R., van Hoeken, D., Oldehinkel, A.J. \& Hoek, H.W. (2014). Prevalence and severity of DSM-5 eating disorders in a community cohort of adolescents. International Journal of Eating Disorders, 47(6), 610-619. doi:1002/ eat.22316.

Sojcher, R., Fogerite, S.G. \& Perlman, A. (2012). Evidence and potential mechanisms for mindfulness practices and energy psychology for obesity and binge-eating disorder. Explore, 8(5), 271-276. doi: 10.1016/j.explore.2012.06.003.

Stice, E., Marti, C.N. \& Rohde, P. (2013). Prevalence, incidence, impairment, and course of the proposed DSM-5 eating disorder diagnoses in an 8-year prospective community study of young women. Journal of abnormal psychology, 122(2), 445. doi:10.1037/ a0030679.

Tester, J.M., Lang, T.C. \& Laraia, B.A. (2016). Disordered eating behaviours and food insecurity: A qualitative study about children with obesity in low-income households. Obesity research \& clinical practice, 10(5), 544-552. doi: 10.1016/j.orcp.2015.11.007

The Economist Intelligence Unit (EIU). (2018). Global food security index 2018: building resilience in the face of rising food insecurity risks. Retrieved from https://foodsecurityindex. eiu.com/ 
West, C. E., Goldschmidt, A. B., Mason, S. M., \& Neumark-Sztainer, D. (2019). Differences in risk factors for binge eating by socioeconomic status in a community-based sample of adolescents: Findings from Project EAT. International Journal of Eating Disorders.

Yadegari, L., Dolatian, M., Mahmoodi, Z., Shahsavari, S. \& Sharifi, N. (2017). The relationship between socioeconomic factors and food security in pregnantwomen. Shiraz E Medical Journal, 18(1). doi:10.17795/ semj41483.
Yau, Y.H. \& Potenza, M.N. (2013). Stress and eating behaviors. Minerva endocrinologica, 38(3), 255. Retrieved from https://pubmed.ncbi.nlm. nih.gov/24126546/

Zulaiha, F. (2018). Pengaruh ibu rumah tangga bekerja terhadap ketahanan pangan rumah tangga di Kecamatan Kemangkon (Bachelor's thesis, UIN Syarif Hidayatullah, Jakarta). Retrieved from from: http://repository.uinjkt. ac.id/dspace/handle/123456789/41958. 